\title{
Stunting Problems in Pregnant Women and Children Within 1000 Days of Early Life
}

\author{
Sabirin B. Syukur ${ }^{1}$, Harismayanti ${ }^{1}$ \\ ${ }^{1}$ Nursing Science, Muhammadiyah University of Gorontalo, Indonesia
}

\begin{abstract}
Pregnant women need nutrients and minerals to support fetal development and metabolic processes because pregnant women are prone to nutritional problems. This study aims to analyze the problem of stunting in pregnant women and children within the first 1000 days of life. This type of research uses a descriptive quantitative approach using analytical survey methods and interviews as well as direct observation of baduta with stunting problems. The sample in this study was conducted using purposive sampling technique with a sample size of 80 Baduta. The results showed the description of mother's knowledge of the problem of stunting in Baduta. Based on table 3 above, there were 47 baduta $(86.7 \%)$ non-stunted mothers (11.3\%). Meanwhile, there were 17 baduta (63.0\%) stunting children and 10 baduta $(37.0 \%)$ children who were not stunted. Several causes that affect children's nutrition that can be at risk and lead to stunting problems, namely low mother's education, lack of knowledge, lack of family income, history of KEK, incomplete immunization, not getting complementary breastfeeding
\end{abstract}

Keywords: Stunting, Mother, Child, Nutrition

Received: October 22, 2020

Received in Revised: November 3, 2020

Accepted: November 13, 2020

\section{Introduction}

The first thousand days represent the most important time in a child's development. A thousand days from the time the baby is in the womb to the birthday of the two children. Pregnancy 270 days plus the first year 365 days and the second year 365 days equals 1,000 days. Those thousand days are a golden opportunity to form healthy and smart children until later (Arisman, 2009).

Pregnant mothers are one of the groups that are prone to experiencing nutritional problems. This is related to the process of fetal development and the development of various organs of the body as support for the pregnancy process (Wadhwa, 2005; King, 2006). Pregnant mothers need a bonus of energy, protein, nutrients and minerals to support fetal development and the body's metabolic processes (Ernawati, 2017; Parenreng et al., 2020). Research on the problem of stunting in a number of studies shows that aspects related to the incidence of stunting in infants. This research views the factors that trigger stunting in infants differently from the research that is to be tried by looking at the donations that can be given in the form of knowing the problem of stunting in children, especially in the first 1000 days of life. is starting from the time of pregnancy until the child is 2 years old to see how the development and growth and fulfillment of Baduta nutrition in the first 1000 days of life. Since the baby is in the womb, he needs a variety of nutrients for growth and development. Mother must be in good health and well nourished. If the mother does not have knowledge of good nutritional intake for her and the fetus, this will be difficult to obtain (Dewey, 2001; Miller et al., 2011; Ruel et al 2013). 
This matter means to identify the problem points of stunting in infants so that linked institutions can control and recognize cases that are in place to improve health services, especially the problems in this research, such as problems in fulfilling nutrition to reduce the effect of stunting in Baduta with the Nutrition Revision of 1000. early days of Life. This study aims to analyze the problem of stunting in pregnant women and children within the first 1000 days of life.

\section{Methods}

This type of research uses a descriptive quantitative approach using analytical survey methods and interviews as well as direct observation of baduta with stunting problems. The population in this study were Baduta (Toddler Two Years) while the sample in this study was carried out by purposive sampling technique with a sample size of 80 Baduta. Data collection techniques used in this study, among others, through questionnaires, interviews, observation, and documentation. The research flow was adjusted to the research method starting with submitting proposals, collecting data, distributing questionnaires and in-depth interviews related to stunting (short) problems in baduta in the first 1000 days.

\section{Results and Discussion}

\section{General Characteristics of Respondents}

Tabel 1. Distribusi Frekuensi Karakteristik Responden

\begin{tabular}{|l|c|c|}
\hline \multirow{2}{*}{ Characteristics } & \multicolumn{2}{|c|}{ Frequency } \\
\cline { 2 - 3 } & n & \% \\
\hline Nutritional Status & & 28,7 \\
\hline Stunting & 23 & 71,3 \\
\hline Normal & 57 & \\
\hline $\begin{array}{l}\text { Sex of Baduta (children } \\
\text { under two years old) }\end{array}$ & & 51,2 \\
\hline Male & 41 & 48,8 \\
\hline Female & 39 & \\
\hline $\begin{array}{l}\text { Age of Baduta (children } \\
\text { under two years old) }\end{array}$ & & 17,5 \\
\hline 0-6 & 14 & 37,5 \\
\hline $7-12$ & 30 & 15,0 \\
\hline $13-18$ & 12 & 30,0 \\
\hline $19-24$ & 24 & \\
\hline
\end{tabular}

Source: Processed Primary Data, 2020

Baduta who experienced stunting were $28.7 \%$. Most of the respondents were male $(51.2 \%)$. Baduta with an age range of 7-12 months (37.5\%) is the largest number.

\section{Frequency Distribution Analysis}

The following will present the analysis of the frequency distribution data of each variable including immunization, complementary breastfeeding, mother's education, mother's knowledge, family income, KEK (Lack of chronic energy).

Table 2. Distribution of Immunization Variables, MP ASI, Mother's Education, Mother's Knowledge, Family Income, KEK (Lack of chronic energy)

\begin{tabular}{|l|l|l|}
\hline No & Variable & Frequency \\
\hline
\end{tabular}




\begin{tabular}{|c|c|c|c|}
\hline & & $\mathrm{n}$ & $\%$ \\
\hline \multirow{3}{*}{1} & Immunization & & \\
\hline & Complete & 53 & 66,2 \\
\hline & Not Complete & 27 & 23,8 \\
\hline \multirow[t]{3}{*}{2} & $\begin{array}{l}\text { Complementary Foods } \\
\text { of Breast Milk }\end{array}$ & & \\
\hline & Get & 61 & 76,2 \\
\hline & Did not get & 19 & 23,8 \\
\hline \multirow[t]{3}{*}{3} & $\begin{array}{l}\text { Mother's } \\
\text { Education }\end{array}$ & & \\
\hline & High & 37 & 46,2 \\
\hline & Low & 43 & 53,8 \\
\hline \multirow[t]{3}{*}{4} & $\begin{array}{l}\text { Mother's } \\
\text { Knowledge }\end{array}$ & & \\
\hline & Enough & 53 & 66,2 \\
\hline & Less & 27 & 23,8 \\
\hline \multirow[t]{3}{*}{5} & Family Income & & \\
\hline & Enough & 37 & 46,2 \\
\hline & Less & 43 & 53,8 \\
\hline \multirow[t]{3}{*}{6} & $\begin{array}{l}\text { KEK (Lack of chronic } \\
\text { energy) }\end{array}$ & & \\
\hline & $>23,5$ & 56 & 70,0 \\
\hline & $<23,5$ & 24 & 30,0 \\
\hline
\end{tabular}

Source: Processed Primary Data, 2020

The most complete distribution of immunization respondents was 53 people $(66.2 \%)$, the distribution of respondents getting the most complementary breastfeeding was 61 people (76.2\%), the distribution of respondents based on the most education of mothers was mothers with low education as many as 43 people $(53,8 \%)$, The distribution of respondents based on maternal knowledge was sufficient knowledge of 53 people $(66.2 \%)$, Distribution of respondents based on family income, the most were 43 people (53.8\%), the distribution of respondents based on history of KEK (Lack of chronic energy) with categories> 23.5, namely 56 people $(70.0 \%)$,

\section{Bivariate Analysis}

The following will present the analysis of the frequency distribution data of each variable (immunization, complementary breastfeeding, mother's education, mother's knowledge, family income, KEK).

Table 3. Variable Distribution of Immunization Descriptions, Complementary Foods to Breastfeeding, Mother's Education, Mother's Knowledge, Family Income, KEK, Against Stunting Problems in the Telaga Health Center Work Area

\begin{tabular}{|c|c|c|c|c|c|c|}
\hline \multirow{2}{*}{ Variable } & \multicolumn{6}{|c|}{ Stunting Case } \\
\cline { 2 - 7 } & \multicolumn{2}{|c|}{ Not Stunting } & \multicolumn{2}{c|}{ Stunting } & \multicolumn{2}{c|}{ Total } \\
\cline { 2 - 7 } & $\mathrm{n}$ & $\%$ & $\mathrm{n}$ & $\%$ & $\mathrm{n}$ & $\%$ \\
\hline Mother's Education & & & & & & \\
\hline High & 33 & 89,2 & 4 & 10,8 & 37 & 100 \\
\hline Low & 24 & 55,8 & 19 & 44,2 & 43 & 100 \\
\hline
\end{tabular}




\begin{tabular}{|l|c|c|c|c|c|c|}
\hline Mother's Knowledge & & & & & & \\
\hline Enough & 47 & 86,7 & 6 & 11,3 & 53 & 100 \\
\hline Less & 10 & 37,0 & 17 & 63,0 & 27 & 100 \\
\hline Family Income & & & & & & \\
\hline Enough & 32 & 86,5 & 5 & 13,5 & 37 & 100 \\
\hline Less & 25 & 58,1 & 18 & 41,9 & 43 & 100 \\
\hline KEK & & & & & & \\
\hline$>23,5$ & 49 & 87,5 & 7 & 12,5 & 56 & 100 \\
\hline$<23,5$ & 8 & 33,3 & 16 & 66,7 & 24 & 100 \\
\hline Immunization & & & & & & \\
\hline Complete & 44 & 83,01 & 9 & 16,9 & 53 & 100 \\
\hline$\quad$ Not Complete & 12 & 44,4 & 15 & 55,6 & 27 & 100 \\
\hline $\begin{array}{l}\text { Complementary foods } \\
\text { with breast milk }\end{array}$ & & & & & & \\
\hline $\begin{array}{l}\text { Get } \\
\text { Did not get }\end{array}$ & 54 & 88,5 & 7 & 11,5 & 61 & 100 \\
\hline
\end{tabular}

Source: Processed Primary Data, 2020

Results of the Analysis of the Overview of Mother's Education on Stunting in Baduta Based on table 3 above, there were 33 Baduta (89.2\%) non-stunting children and 4 Baduta (10.8\%) stunted children. Meanwhile, there were 19 poorly educated mothers who were stunted (44.2\%) and 24 children who were not stunted (55.8\%). Results of the Analysis of Mother's Knowledge Overview of the Problem of Stunting in Baduta Based on table 3 above, there were 47 baduta $(86.7 \%)$ non-stunting children and 6 Baduta $(11.3 \%)$ stunted children. Meanwhile, there were 17 baduta (63.0\%) stunting children and 10 baduta (37.0\%) children who were not stunted.

Results of the Analysis of the Image of Head of Household Income to the Problem of Stunting in Baduta. Based on table 5.3 above, sufficient family income is obtained by 32 baduta $(86.5 \%)$ non-stunting children and 5 Baduta (13.5\%) stunted children. While the less family income obtained by children who are stunted are 18 baduta $(41.9 \%)$ and children who are not stunted are 25 baduta $(58.1 \%)$.

Results of Analysis of the Overview of KEK on Stunting Problems in Baduta Based on table 5.3 above, mothers who had a KEK> 23.5 during pregnancy found that there were 49 children who were not stunted $(87.5 \%)$ and children who were stunted as many as 7 Baduta $(12.5 \%)$. Meanwhile, mothers who had KEK <23.5 during pregnancy found 16 baduta $(66.7 \%)$ stunted children and 8 baduta $(33.3 \%)$ non-stunted children.

Results of Analysis of Immunization Overview of Stunting Problems in Baduta. Based on table 5.3 above, there were 44 baduta (83.0) children who were not stunted and 9 baduta (17.0\%) who were stunted. Meanwhile, 15 baduta (55.6\%) stunted children were stunted and 12 baduta $(44.4 \%)$ were not stunted.

Results of the Analysis of the Image of MP ASI Against Stunting Problems in Baduta Based on table 5.3 above, there were 54 baduta (88.5\%) non-stunting children who were not stunted and 7 Baduta (11.5\%) stunting children. Meanwhile, the baduta who did not get MP ASI were found as many as 16 baduta (84.2\%) stunted children and 3 baduta (15.8\%) children who were not stunted. 
A pregnant woman who is malnourished, her baby will be dangerous to face obstacles in development and growth, die in a natural womb, cognitive and physical constraints for life, have chronic health problems. Nutrition received by children in the period of 1,000 days of early life affects skills children to study and work. Malnutrition is still the number one trigger for child deaths. Malnutrition in children under the age of 2 years has an adverse effect that is difficult to restore to its original state and tends to affect adulthood. The result of malnutrition in children aged at the base of the first 1,000 days is as follows, giving rise to death; weakens the immune system so that children are susceptible to contracting pneumonia, diarrhea, and malaria. (Fikawati et al., 2015).

The positive impact if children find the right nutrition during the first 1,000 days, namely saving more than 1 million lives each year who are about to die from malnutrition, reducing the burden on citizens and the economy because they are free from tuberculosis, HIV/AIDS, and malaria, reduce the effect of developing non-widespread diseases such as diabetes and other chronic conditions in the elderly, increasing learning achievement and income ability, increasing Gross Dosmetic Gross, is the amount of state income, at least 2 to 3 percent per year (Soetjiningsih, 2012). The bad effects of stunting that haunt old age make this condition very important to prevent. Good nutrition and a healthy body are the keys to preventing stunting.

\section{Conclusion}

Several causes that affect children's nutrition that can be at risk and lead to stunting problems, namely low mother's education, lack of knowledge, lack of family income, history of chronic energy deficiency (KEK), incomplete immunization, not getting complementary foods with breast milk.

\section{References}

Arisman, M. B. (2009). Buku ajar ilmu gizi: Gizi dalam daur kehidupan. Jakarta: Penerbit Buku Kedokteran EGC, 2, 275.

Dewey, K. G. (2001). Nutrition, growth, and complementary feeding of the brestfed infant. Pediatric Clinics of North America, 48(1), 87-104.

Ernawati, A. (2017). Masalah gizi pada ibu hamil. Jurnal Litbang: Media Informasi Penelitian, Pengembangan dan IPTEK, 13(1), 60-69.

Fikawati, S., Syafiq, A., \& Karima, K. (2015). Gizi ibu dan bayi. Jakarta: Rajawali Pers, 8994.

King, J. C. (2006). Maternal obesity, metabolism, and pregnancy outcomes. Annu. Rev. Nutr., 26, 271-291.

Miller, J. L., Lynn, C. H., Driscoll, D. C., Goldstone, A. P., Gold, J. A., Kimonis, V., \& Driscoll, D. J. (2011). Nutritional phases in Prader-Willi syndrome. American journal of medical genetics Part A, 155(5), 1040-1049.

Parenreng, K. M., Bahar, B., Jafar, N., Hidayanty, H., \& Saleh, L.M. (2020). Determinants of Stunting Events in Children Aged 6-23 Months in Locus and Non-Locus Areas in East Luwu Regency. Journal La Medihealtico, 1(6), 7-6.

Ruel, M. T., Alderman, H., \& Maternal and Child Nutrition Study Group. (2013). Nutritionsensitive interventions and programmes: how can they help to accelerate progress in improving maternal and child nutrition?. The lancet, 382(9891), 536-551. 
Soetjiningsih, (2012). Tumbuh Kembang Anak. Jakarta: EGC.

Wadhwa, P. D. (2005). Psychoneuroendocrine processes in human pregnancy influence fetal development and health. Psychoneuroendocrinology, 30(8), 724-743 